\title{
Media Massa Dalam Komunikasi Pembangunan
}

\author{
Tomi Hendra \\ Institut Agama Islam Negeri Bukittinggi \\ (E-mail: tomihendra05@gmail.com)
}

\begin{abstract}
In the current era of technology, the development of society in social life is very dependent on mass media, where mass media has a very important role in this matter. One of the important roles of mass media for the community is as a provider of information, education, and entertainment for the community so that in this way the community is motivated, affected and strives to change the mindset and perspective in life. In addition, the presence of mass media greatly helps the development process in the lives of social communities. Along with technological advancements that are closely related to mass media, it cannot be denied that the growth of people's lives will also be more complete. With the development of mass media at this time the community is able to respond and be smarter towards the reality around the effects of the growth of the dynamics of their lives.
\end{abstract}

Keywords: Mass Media in Development communication

Abstrak: Di Era teknologi saat ini, perkembangan masyarakat dalam kehidupan sosial sangat tergantung akan media massa, dimana media massa sangat memiliki peran dalam hal tersebut. Salah satu peran penting media massa bagi masyarakat yaitu sebagai pemberi informasi, pendidikan, dan hiburan bagi masyarakat sehingga dengan hal demikian masyarakat termotivasi, terpengaruh dan berusaha untuk merubah pola pikir serta cara pandang dalam kehidupan. Selain itu kehadiran media massa sangat membantu proses pembangunan dalam kehidupan masyarakat sosial. Seiring dengan kemajuan teknologi yang erat hubungannya dengan media massa tidak dapat dipungkiri bahwa pertumbuhan kehidupan masyarakat juga akan semakin lengkap. Dengan perkembangan media massa saat ini masyarakat mampu merespon dan bisa lebih cerdas terhadap realitas yang ada di sekitar efek dari pertumbuhan dinamika kehidupannya.

Kata kunci: Media Massa Dalam komunikasi Pembangunan 
137 Tomi Hendra, Media Massa dalam Komunikasi Pembangunan Jurnal At-Taghyir : Jurnal Dakwah dan Pengembangan Masyarakat Desa Volume 1 Nomor 2 Juni 2019, h. 136-152

\section{A. Pendahuluan}

Media massa menjadi sebuah media infomasi yang tidak bisa dilepaskan dari kehidupan masyarakat sosial dalam mendapatkan berbagai informasi. Dalam hal ini media massa memiliki peran penting dalam perkembangan dan kemajuan pola piker serta cara pandang dalam kehidupan masyarakat. Denis Mc Quail mengungkapkan bahwa media massa merupakan sebagai alat control, manajemen, dan inovasi bagi masyarakat yang dapat didaya gunakan untuk pengganti kekuatan lainnya. Tidak bisa dielakkan lagi bahwa media massa menjadi bagian yang sangat berperan penting bagi masyarakat sosial yang sangat erat kaitannya dengan informasi. Namun di sisi yang berbeda tidak bisa kita pungkiri bahwa banyak juga dari kalangan masyarakat tertentu yang bersikap apartis terhadap kehadiran media massa di tengah-tengah rutinitas masyarakat. Hal itu disebabkan karena ketidak seimbangan sebuah media massa dalam memberikan informasi dan pandangan kepada pihak tertentu.

Dalam perkembangannya, tidak bisa dielakkan lagi bahwa media massa telah memainkan perannya sebagai alat sosial media yang banyak dimanfaatkan oleh pihakpihak tertentu dalam mencapai sebuah tujuan, baik itu untuk kepentingan individu, lembaga sosial maupun kepentingan sebuah organisasi. Dimana Tede menjelaskan bahwa media massa memiliki kekuatan untuk mengendalikan wawasan khalayak orang banyak melalui apa yang disampaikan dan apa yang tidak disampaikan secara langsung, dengan argumentasi yang berbeda bahwa apa yang disiarkan oleh sebuah media massa mampu mempengaruhi cara pandang masyarakat terhadap suatu kondisi. Selain itu media massa memilik peran yang sangat signifikan dalam kehidupan sosial masyarakat, yang mana salah satu tujuan dasarnya yaitu menyampaikan berbagai macam bentuk informasi kepada masyarakat luas. Dalam proses pembangunan media massa memiliki peran yang dapat menentukan serta memberikan akan pemahaman yang lebih akan suatu hal bagi masyarakat yang sedang berkembang. Maka dari itu penulis tertarik untuk mengkaji persoalan sosial yang berkembang di tengah- tengah kehidupan masyarakat. Untuk lebih lanjutnya penulis tertarik untuk membahas masalah terkait dengan media massa dan komunikasi pembangunan. 
138 Tomi Hendra, Media Massa dalam Komunikasi Pembangunan Jurnal At-Taghyir : Jurnal Dakwah dan Pengembangan Masyarakat Desa Volume 1 Nomor 2 Juni 2019, h. 136-152

\section{B. Pembahasan}

\section{Pengertian Media Massa dalam Pembangunan \\ a. Pengertian Media Massa dalam Pembangunan}

Komunikasi massa merupakan sebuah proses penyampaian pesan, dari komunikator kepada komunikan, dalam hal ini khalayak ramai. Dimana dalam proses penyampaian pesan tersebut menggunakan sebuah media perantara untuk menghubungkan satu sama lain dengan tujuan agar pesan tersebut bisa tersampaikan dan bisa dipahami oleh khalayak. Sementara itu, menurut bahasa kata Media berasal dari bahasa latin yaitu medius yang mana secara harfiah diartikan sebagai perantara atau pengantar. sedangkan media di dalam bahasa Inggris merupakan asal kata dari medium yang merupakan sebagai bentuk jamaknya dengan arti tengah, antara, rata-rata. Para ahli mengartikan media sebagai sebuah alat penghubung, dimana menghubungkan antara si penyampai pesan yang dikenal dengan istilah komunikator dengan yang menerima pesan di sini disebut dengan istilah komunikan. Sementara itu dalam bahasa Arab media dikenal dengan kata Wasilah yang dikenal dalam bentuk jamak Wasail yang berarti alat atau perantara. ${ }^{1}$

Menurut bentuk dan fungsinya media dapat dibedakan menjadi tiga bentuk yaitu pertama, sebagai Media terucap atau dikenal dengan The Spoken Words yang berfungsi sebagai alat bias untuk mengeluarkan bunyi seperti radio, telepon, dan sejenisnya. Kedua, sebagai media tulis atau the printed writing yaitu media berupa tulisan atau cetakan yang dapat dinikmati oleh pembaca seperti tabloid, bulletin, majalah, Koran, buku dan pamphlet. Ketiga, sebagai media dengar pandang atau yang dikenal dengan the audio visual yang mampu menyampaikan pesan baik dalam bentuk audio yang mampu di dengar maupun dalam bentuk gambar atau visualiasi yang dapat dilihat dan dinikmati sehingga pesan yang hendak disampaikan dapat diterima dengan baik oleh khalayak ramai seperti televise. $^{2}$

Selain penjelasan di atas ada juga yang mengklasifikasikan media dari perspektif yang berbeda, yaitu media dilihat dari perspketif media dalam berdakwah yang dibagi dalam bentuk dua bagian, pertama, media secara tradisional dimana dalam hal ini

\footnotetext{
${ }^{1}$ Moh. Ali Aziz, Ilmu Dakwah, (Jakarta: Kencana, 2009), hlm. 403

${ }^{2}$ Ibid, 406-407
} 
139 Tomi Hendra, Media Massa dalam Komunikasi Pembangunan Jurnal At-Taghyir : Jurnal Dakwah dan Pengembangan Masyarakat Desa

Volume 1 Nomor 2 Juni 2019, h. 136-152

dimaksud media yang tidak menggunakan teknologi komunikasi dan kedua, dikenal dengan media modern yang sudah mengadopsi dan memanfaatkan akan kemajuan teknologi sesuai dengan perkembangan zaman saat ini, di dalam al-Quran surat an-Nahl ayat 78, Allah Swt berfirman yang artinya, "Dan Allah mengeluarkan kamu dari perut ibumu dalam keadaan tidak mengetahui sesuatupun, dan dia memberi kamu pendengaran, penglihatan dan hati, agar kamu bersyukur". Selain itu Allah swt berfirman dalam surat al-mu'minun ayat 78 yang artinya," dan Dialah yang telah menciptakan bagi kamu sekalian, pendengaran, penglihatan dan hati. Amat sedikitlah kamu bersyukur.

Dari firman Allah tersebut, Al-Razi mengungkapkan Al-Af'idah adalah pengetahuan, sedangkan Ibnu Jarir al-Thabari mengasumsikan Al-Af'idah adalah sebagai aneka hati yang bisa mengetahui segala sesuatu hingga bisa mengingat, memikirkan dan mengingat. Sedangkan itu media persepsi yang mencakup aneka hati, pengetahuan asumtif, kecerdasan mengikuti media sensasi. Sedangkan media sensasi yang paling dominan adalah media auditif dan media visual. Dari hubungan kedua media tersebut, maka media terbagi menjadi beberapa bagian, yakni: media visual atau media cetak, media elektronik dan media audio visual.

\section{1) Media visual atau medi cetak}

Di dalam pembahas jurnalistik istilah pers sering di dengan dan dipelajarai. Dimana istilah "pers" berasal dari bahasa belanda, sementara itu dalam bahasa inggris dikenal dengan press. Secara harfiah dapat kita artikan cetak atau maknawiyah berarti penyiaran secara tercetak atau publikasi secara tercetak. Dalam perkembangan pers memiliki dua pengertian, yaitu pers dalam arti sempit yang hanya terbatas pada media cetak semata seperti surat kabar, majalah, dan bulletin. Pers dalam pemahaman luas dapat meliputi segala penerbitan, bahkan termasuk media elektronik, seperti radio siaran dan televisi siaran.

Pers dalam uu no. 40 tahun 1999 merupakan sebuah lembaga sosial dan wahana komunikasi massa yang melaksanakan kegiatan jurnalistik yang meliputi mencari, memdapatkan, memilih, menyimpan, mengolah, dan kemudian menyampaikan hasil olah tadi yang dikenal dengan informasi baik dalam bentuk tulisan, suara, gambar serta data dan grafik maupun dalam bentuk lainnya dengan menggunakan media cetak, 
140 Tomi Hendra, Media Massa dalam Komunikasi Pembangunan Jurnal At-Taghyir : Jurnal Dakwah dan Pengembangan Masyarakat Desa Volume 1 Nomor 2 Juni 2019, h. 136-152

media elektronik, dan segala saluran yang tersedia. Sedangkan selain pres dapat dipahami sebagai sebuah kegiatan yang dilaksanakan di dalam mendapatkan sebuah informasi dari sebuah peritiwa di lapangan yang kemudian disebarkan dalam bentuk informasi yang tercetak. Dalam hal ini, secara umum pers memiliki fungsi sebagai berikut,

\section{1) Memberikan informasi}

Berfungsi sebagai pemberi informasi pers berkewajiban untuk memenuhi kebutuhan dan keingintahuan masyarakat luas tentang sebuah informasi. Untuk mewujudkan fungsi ini, pers menyajikan berbagai macam informasi baik itu bersumber dari fakta (baik dari apa saja yang ada maupun dari apa saja yang telah terjadi) yang penting dalam hal ini menarik bagi masyarakat luas.

2) Memberikan pendidikan

Sebagai pemberi pendidikan, pers harus bisa memberikan pendidikan politik, pendidikan moral, pendidikan hokum dan bahkan memberikan pengetahuan yang belum atau tidak diperoleh di lembaga-lemabaga pendidikan. Hal itu terjadi karena informasiinformasi baru jauh lebih cepat diperoleh melalui media massa dari pada media lembaga pendidikan yang memerlukan sebuah proses dan waktu yang cukup lama.

3) Memberikan hiburan

Selain memberikan informasi pers mampu memberikan sebuah hiburan bagi masyarakat luas melalui pemberitaan yang bisa berupa informasi yang mengembirakan bagi masyarakat, seperti informasi kebijakan tentang bantuan dana pendidikan, beasiswa dan infromasi lainnya yang mampu memberikan hiburan kepada pembaca.

4) Melakukan control sosial

Salah satu lembaga yang mempunyai wewenang dan kekuatan besar dalam melakukan control sosial ialah pers. Banyak cara pers dalam melakukan control sosial, antara lain, pertama, memberitakan terkait dengan pelanggaran hokum yang dilakukan oleh suatu lembaga atau yang dilakukan seseorang. Kedua, memberitakan kesalahan pelaksanaan proyek pembangunan, ketiga, memberitakan kritikan yang dilakukan oleh seseorang atau suatu lembaga sosial tentang suatu kebijakan, keempat, bisa memberitakan terkait dengan perilaku yang dilakukan oleh seseorang yang merugikan 
141 Tomi Hendra, Media Massa dalam Komunikasi Pembangunan Jurnal At-Taghyir : Jurnal Dakwah dan Pengembangan Masyarakat Desa

Volume 1 Nomor 2 Juni 2019, h. 136-152

pihak lain, kelima, memberikan informasi atau memberitakan terkait dengan suatu kejanggalan yang terjadi atau ditemui di lapangan.

Dari fungsi pers di atas dapat kita pahami bahwa pers memiliki peran yang sangat singnifikan dalam kehidupan masyarakat sosial, baik dari sisi sebagai control sosial maupun dari sisi informasi dan hiburan. Selain pers ada bentuk media informasi yang banyak beredar di tengah-tengah masyarakat, yang dikenal dengan nama majalah. Dimana majalah juga menyampaikan informasi yang sangat bermanfaat untuk perkembangan dan penambahan wawasan masyarakat. Sebagaimana pers majalah juga memiliki kekuatan dan pengaruh sebagaimana pers atau surat kabar, yang mana hal itu dibagi lima kategori, pertama, General consumer umum (majalah konsumen umum), dimana majalah ini biasa dikonsumsi atau dibaca oleh masyarakat umum untuk mendapatkan sebuah informasi atau mendapatkan hiburan semata. Kedua, Business pulication (majalah bisnis), dimana biasanya majalah ini dibaca oleh kalangan masyarakat yang memiliki profesi sebagai pebisnis yang bertujuan untuk mengatahui perkembangan terbaru terkait dengan dunia bisnis selain itu juga untuk melihat dan mengetahui inovasi terbaru di dalam dunia bisnis, ketiga, Literacy reviews and academic journal (kritik sastra dan majalah ilmiah, yaitu terbitan berkala yang berisi kajian-kajian ilmiah yang spesifik dalam bidang tertentu), keempat, Newsletter (majalah khusus terbitan berkala) dan kelima, Public relations magazines (majalah humas).

Majalah ada juga media lain yang berfungsi dan memiliki peran dalam menyampaikan informasi yaitu surat. Surat dapat didefenisikan sebagai sebuat tulisan yang berisi tentang pernyataan atau ungkapan dari sebuah penulisan yang dibuat dengan sengaja bertujuan untuk menyampaikan informasi kepada pihak lain. Surat mempunyai fungsi sebagai wakil dari pengirim surat, sebagi bahan bukti, sebagai pedoman untuk mengambil tindakan lebih lanjut, sebagai alat pengukur tindakan lebih lanjut dari suatu masalah, dan sebagai sarana untuk memperpendek jarak. Tidak hanya majalah sebagai media dalam penyampai informasi tetapi poster atau plakat dapat dimanfaatkan dalam menyampaik sebuah pesan kepada khalayak ramai. Dimana Poster atau plakat merupakan sebuah karya seni atau desain grafis yang sengaja didesain semenarik mungkin dengan memperhatikan dari komposisi gambar dan huruf yang dituangkan diatas kerta yang berukuran besar sehingga mampu menyampaikan pesan yang 
142 Tomi Hendra, Media Massa dalam Komunikasi Pembangunan Jurnal At-Taghyir : Jurnal Dakwah dan Pengembangan Masyarakat Desa Volume 1 Nomor 2 Juni 2019, h. 136-152

dimaksud dan mempunyai nilai seni tersendiri di dalam penyampaian informasi atau pesan kepada khalayak ramai. Dimana dalam aplikasinya poster atau plakat di temple atau dipajang di dinding yang memiliki permukaan datar yang mampu menarik perhatian mata sebanyak mungkin dan mampu mempengaruhi yang melihat sesuai dengan isi pesan yang tertuang di dalam poster atau plakat tersebut.

\section{2) Media Elektronik}

Dalam komunikasi massa terdapat media elektronik yang berfungsi sebagai media di dalam menyalurkan dan meyampaikan informasi yang telah diolah untuk disampaikan kepada khalayak ramai. Dalam hal ini medi elektronik dapat kita bagi menjadi dua bagian, pertama media auditif atau yang dikenal dengan media audio dan yang kedua media audio-viduo yang memiliki dua daya tarik pertama pada audio dan yang kedua pada tampilan yang bisa disaksikan oleh masyarakat. Dimana kedua media ini memiliki sifat yang masing-masing berbeda. Pertama, Media Auditif, atau yang dikenal dengan media yang memiliki kekuatan pada audio atau suara. Karena kekuatan radio terletak pada audio atau suara yang begitu kuat sampai-samapai media radio mendapat julukan the fifth estate (kekuasaan kelima) setelah surat kabar sebagai the fourth estate (kekuasaan keempat) pada sebuah bangsa. Dalam sejarah kemerdekaan Indonesia media Radio menjadi media pertama dalam menyampaikan kemerdekaannya. Hal ini disebabkan karena media ini mempunyai beberapa sifat yang diantaranya: Bersifat langsung artinya disini di dalam menyampaikan informasi atau pemberitaan penyiar langsung menyampaikan pesan tersebut kepada pendengarnya, Tidak mengenal jarak dan rintangan, dalam hal ini karena radio menggunakan gelombang elektromaknetik sehingga dalam media ini tidak mengenal istilah hambatan dalam menyampaikan informasi selagi ada akses, Siaran mempunyai daya tarik yang kuat, Biayanya relatif murah, Mampu menjangkau tempat-tempat terpencil, Tidak terhambat oleh kemampuan baca dan tulis. Selain media audio atau radio ada satu lagi media yang memiliki kekuatan pada audionya yaitu Cassete atau Tape Recorder. Dimana pada media ini memiliki fungsi untuk merekam suara yang ditangkapnya dan kemudian disiarkan atau didengarkan kembali terhadap informasi yang didapatkan ketika berada di lapangan. 
143 Tomi Hendra, Media Massa dalam Komunikasi Pembangunan Jurnal At-Taghyir : Jurnal Dakwah dan Pengembangan Masyarakat Desa Volume 1 Nomor 2 Juni 2019, h. 136-152

\section{3) Media Audio Visual}

Media audio visual merupakan bahagian dari media massa yang memiliki peran penting dalam menyampaikan informasi kepada khalayak ramai. Selain itu media ini memiliki kekuatan yang berbeda bila dibandingkan media audio, dimana media memiliki memiliki daya tarik baik dari segi audio maupun dari segi visual yang mampu mempengaruhi khalayak ramai atau penontonnya. Karena pada media massa yang satu ini selain bisa didengar tetapi bisa langsung saksikan gambar yang terkait dengan apa yang disampaikan lewat audio. Salah satu bentuk media yang menjadi bahagian dari media audio visual ini adalah televise. Televise merupakan sebuah alat pelengkap siaran yang memiliki tampilan gambar dan pendukung pada audio. Selain itu televisi merupakan salah satu media massa yang mempunyai pengaruh yang cukup efektif dalam menyampaikan informasi kepada khalayak ramai. Kehadiran televisi sebagai media komunikasi bisa membawa dampak positif maupun negatif, tergantung bagaimana memanfaatkan media tersebut. Media televisi adalah media audio visual yang disebut juga media dengar pandang. ${ }^{3}$

Dalam hal ini, kekuatan dan kelemahan dari televise. Sebagai media massa yang tumbuh belakangan dan merupakan konvergensi dari media radio, surat kabar, industry music dan sebagainya televise memiliki kekuatan yang sangat besar bila dibandingkan dengan media massa lainnya. Meskipun internet belum mampu mengeser dominasi televise. Dimana-mana persentase penggunaan jenis media massa masih dikuasai oleh televise. Kemampuan televise mendominasi media lain karena media ini mempunyai sejumlah kelebihan, antara lain sebagai berikut, pertama, bersifat dengar-pandang. Berbeda dengan radio yang hanya bisa dinikmati pada bagian audio melalui indra pendengaran, sementara itu televise bisa dinikmati dengan dua pancara indra yang ada pada manusia, yaitu pendengaran dan penglihatan. Dengan adanya penampilan dari audio masyarakat dapat menyaksikan langsung rangkaian peristiwa yang terjadi. Kedua, menghadirkan relaitas sosila, terkait dengan potensi baru saja disebutkan bahwa televise memiliki kemampuan dalam menghadirkan relaitas sosial seolah-olah seperti realnya. Hal ini disebabkan karena kemampuan dari kamera dalam merekam semua realitas sesuai dengan yang asli. Ketiga, simultaneous, dimana kekuatan lain yang dimiliki oleh

\footnotetext{
${ }^{3}$ Samsul Munir Amin, Rekonstruksi Pemikiran Dakwah Islam,(Jakarta: Amzah, 2008), hlm. 192
} 
144 Tomi Hendra, Media Massa dalam Komunikasi Pembangunan Jurnal At-Taghyir : Jurnal Dakwah dan Pengembangan Masyarakat Desa Volume 1 Nomor 2 Juni 2019, h. 136-152

media televise adalah kemampuan menyampaikan segala sesuatu secara serempak sehingga mampu menyampaikan informasi kepada banyak orang yang tersebar di berbagai wilayah dalam waktu yang sama persis.

\section{b. Media Internet atau Online}

Salah satu media massa yang banyak diakses oleh masyarakat untuk mendapatkan informasi adalah internet. Internet sendiri merupakan suatu jaringan system komunikasi yang banyak terhubung di seluruh dunia. Dalam hal ini antusias masyarakat dunia sangat tinggi dalam memanfaatkan internet untuk berbagai macam bentuk kepentingan mulai untuk perdangana, politik, perang persepsi,serta banyaknya juru dakwah yang sudah mulai memanfaatkan internet sebagai media dan sarana dakwah. Dalam hal ini ini media massa internet sangat memiliki potensi yang sangat besar sebagai media massa, ini dapat dilihat dengan mengedepankan berbagai alasan sebagai berikut; mampu menembus batas ruang dan waktu dalam waktu reletif pendek atau dalam sekejap dan tentu dengan biaya dan dengan menggunakan energy yang relative terjangkau, selain itu dalam hal dakwah, para pakar atau ulama bisa lebih konsentrasi dalam menyikapi setiap wacana dan peristiwa yang sedang menjadi hangat untuk dibahas, internet menjadi tempat yang pas bagi mereka yang ingin berdiskusi, selain itu pemilihan dan pemanfaatan media internet untuk dakwah sudah menjadi pilihan tersendiri bagi masyarakat. Hadirnya berbagai macam dan ragam jenis situs dakwah yang mampu diakses oleh masyarakat yang membuat mereka mampu menerima keanekaragam dan fariasi dakwah yang telah berkembang sehingga tidak menimbulkan sikap manatiksisme. ${ }^{4}$

Lebih lanjut lagi, selain sebagai media saluran dan alat komunikasi massa. Dalam hal ini komunikasi massa dapat diartikan sebagai komunikasi saluran yang mampu menyentuh khalayak ramai. Hal ini disebabkanm karena media massa memilik peran yang besar dalam mempengaruhi dan mengubah cara pandang serta berpikir bagi

${ }^{4}$ N. Faqif Syarif,Menjadi Dakwah Yang Dicintai:Menyampaikan Dakwah Dengan Cara Yang Efektif,(Jakarta: Gramedia Pustaka Utama, 2011),hlm. 134-135 
145 Tomi Hendra, Media Massa dalam Komunikasi Pembangunan Jurnal At-Taghyir : Jurnal Dakwah dan Pengembangan Masyarakat Desa Volume 1 Nomor 2 Juni 2019, h. 136-152

masyarakat. ${ }^{5}$ Media massa sebagai sarana yang sering dimanfaatkan oleh khalayak ramai dalam memperoleh informasi dan berbagai hiburan.

\section{Media Massa Berperan Dalam Komunikasi Pembangunan}

Sebagai salah satu institusi yang sangat berperan dalam perubahan tatanan kehidupan masyarakat, media dikenal juga sebagai pelopor perubahan, sehingga hal ini menjadi paradigma utama media massa. Sementara itu dalam proses pembangunan media massa memiliki peran yang sangat besar yaitu:

a. Sebagai institusi yang memberikan pencerahan kepada masyarakat luas, yaitu memiliki peran sebagai media edukasi. Dimana media massa menjadi media yang setiap saat mendidik masyarakat supaya cerdas, terbuka pikirannya, dan menjadi masyarakat yang maju.

b. Media massa juga berperan sebagai media informasi, yaitu media yang setiap saat menyampaikan berbagai macam informasi kepada masyarakat. Dengan informasi yang terbuka, jujur, dan benar disampaikan media mssa kepada masyarakat, maka masyarkat menjadi akan menjadi masyarakat yang kaya dengan informasi. Masyarakat yang terbuka dengan informasi. Selain itu, informasi yang banyak dimiliki oleh masyarakat, menjadikan masyarakat sebagai masyarakat dunia yang dapat berpatisipasi dengan berbagai kemapuannya.

c. Media massa juga berperan sebagai media hiburan. Media massa juga menjadi institusi budaya, yaitu institusi yang setiap menjadi corong kebudayaan, katalisator perkembangan budaya. Sebagai agent of change yang dimaksud adalah juga mendorong agar perkermbangan budaya bagi manusia bermoral dan masyarakat sakinah, dengan demikian media massajuga berperan untuk mencegah berkembangnya budaya-budaya yang justru merusak peradaban manusia dan masyarakatnya.

Secara lebih spsifik peran media massa lebih menyentuh persoalan-persoalan yang terjadi di masyarakat secara actual, seperti:

a. Harus lebih spsifik dan profesional dalam melihat sebuah persoalan sehinnga mampu menjadi media edukasi dan media informasi sebagaimana diharapkan oleh masyarakat.

${ }^{5}$ Kacung Marijan, System Politik Indonesia: Konsilidasi Demokrasi Pasca- Orde Baru, (Jakarta: Kencana, 2010), hlm, 282 
146 Tomi Hendra, Media Massa dalam Komunikasi Pembangunan Jurnal At-Taghyir : Jurnal Dakwah dan Pengembangan Masyarakat Desa Volume 1 Nomor 2 Juni 2019, h. 136-152

b. Dalam memotret realitas, media massa harus fokus pada realita masyarakat, bukan pada potret kekuasaan yang ada dimasyarakat itu, sehingga informasi tidak menjadi propaganda kekuasaan, potret figure kekuasaan.

c. Sebagai lembaga edukasi, media massa dapat memilah kepentingan pencerahan dengan kepentingan media sebagai lembaga edukasi, sehingga kasus-kasus pengaburan berita dan iklan tidak harus terjadi dan merugikan masyarakat.

d. Media massa juga harus menjadi early warning system, hal ini terkait dengan peran media massa sebagai media informasi, dimana lingkungan saat ini menjadi sumber ancaman. Media massa menjadi sebuah system dalam system besar peringatan terhadap ancaman lingkungan, bukan hanya menginformasikan informasi setelah terjadi bahaya dari lingkungan itu.

e. Dalam hal menghadapi ancaman masyrakat yang lebih besar seperti terorisme, seharusnya media massa lebih banyak menyoroti aspek fundamental pada terorisme seperti mengapa terorisme itu terjadi bukan bukan hanya pada aksi-aksi terorisme. ${ }^{6}$

Selanjutnya, peranan kuat media massa dalam pembangunan kemudian diimplikasikan dalam penelitian Lerner dan Rao dan studi-studi lain pada 1950 dan 1960-an. Studi-studi ini melengkapi hepotesis paradigma pembangunan dominan. Media massa merupakan alat untuk mentransfer gagasan-gagasan dan model-model baru dari Negara-negara berkembang ke Negara-negara Dunia Ketiga dan dari daerahdaerah. Schramm menjelaskan pemikiran dominan dalam periode historis dalam bukunya, Mass Media and National Development.Ia menjelaskan bahwa di Negara Dunia Ketiga, "desa-desa tidak menyadari pola-pola hidup tradisional mereka... tuntutan untuk berkembang secara ekonomis dan sosial biasanya berasal dari bagaimana negara-negara berkembang atau orang-orang yang lebih beruntung hidup". Pada tingkat makro makro, media massa modern sangat untuk pembangunan. Mereka digunakan dalam kemunikasi satua arah dan atas bawah oleh para pemimpin untuk mempublikasikan inovasi-inovasi modern kepada public. Jelas bahwa media semakin berkembang pada tahun 1950-an dan 1960-an. Literasi semakin menyebar luas di Negara-negara maju, yang membawa pengesposan media cetak yang lebih luas. Radio-

${ }^{6}$ M. Burhan Bungin, Sosiologi Komunkiasi: Teori, Paradigm Dan Diskursus Teknologi Komunikasi Di Masyarakat,(Jakarta: Kencana Prenada Media Group),hlm. 85-87 
147 Tomi Hendra, Media Massa dalam Komunikasi Pembangunan Jurnal At-Taghyir : Jurnal Dakwah dan Pengembangan Masyarakat Desa Volume 1 Nomor 2 Juni 2019, h. 136-152

radio memasuki setiap desa.Aliran komunikasi satu arah dari badan-badan pembangunan pemerintah ke masyarakat diimplikasikan dalam paradigma dominan. Media massa tampak ideal bagi peranan ini. ${ }^{7}$ Sikap adalah suatu bangun psikologis yang dapat berbentuk sikap individual dan sikap sosial. Sikap individu adalah sikap yang diyakini oleh individu, sedangkan sikap sosial adalah sikap yang diyakini sekelompok orang terhadap suatu objek. ${ }^{8}$ Media massa mampu mempengaruhi pemikiran maupun tindakan khalayak. Budaya, sosial, dan politik dipengaruhi oleh media. Media membentuk opini publik untuk membawa seseorang pada perubahan.

\section{Fungsi Media dalam Pembangunan}

Dalam proses pembangunan, media memili peran dan fungsi tersendiri yang memegang peran penting khususnya terkait dengan fungsi sebagai jembaran keduniaan yang sagat luas. ${ }^{9}$. di antara fungsi tersebut sebagai berikut;

a. To Infrom yaitu menginfomasikan kepada pembaca secara objektif tentang apa yang terjadi dalam suatu komunitas, Negara, dan dunia. Dalam hal ini media berfungsi menyampaikan berbagai macam bentuk informasi secara objektif kepada masyarakat luas.

b. To Comment yaitu mengomentari berita yang disampaikan dan mengembangkannya ke dalam fokus berita.

c. To Provide yaitu menyediakan keperluan informasi bagi pembaca yang membutuhkan barang dan jasa melali pemasangan informasi di media.

Fungsi sekunder media, yaitu:

a. Untuk mengempanyekan proyek-proyek yang bersifat kemasyarakatan, yang sangat diperlukan untuk membantu kondisi-kondisi tertentu

b. Memberikan hiburan kepada pembaca dengan sajian cerita

c. Melayani pembaca sebagai konselor yang ramah, menjadi agent informasi dan memperjuangkan hak. ${ }^{10}$

\footnotetext{
${ }^{7}$ Rochajat Harun dan Elvinaro Ardianto, Komunikasi Pembangunan Perubahan Sosial, (Jakarta: Rajawali Pers, 2012), hlm. 130-132

${ }^{8}$ Isbandi Rukminto Adi, Psikologi Pekerjaan Sosial Dan Ilmu Kesejahteraan Sosial, Dasa-Dasar Pemikiran, (Jakarta: Raja Grafindo Persada), hlm. 178

${ }^{9}$ Rochajat Harun dan Elvinaro Ardianto, Komunikasi Pembanunan Perubahan Sosial, (Jakarta: Rajawali Pers, 2012), hlm. 130

${ }^{10}$ Moh. Ali Aziz, Ilmun Dakwah,(Jakrat: Kencana, 2009), hlm. 414
} 
148 Tomi Hendra, Media Massa dalam Komunikasi Pembangunan Jurnal At-Taghyir : Jurnal Dakwah dan Pengembangan Masyarakat Desa Volume 1 Nomor 2 Juni 2019, h. 136-152

Selanjutnya, untuk menyederhanakan fungsi media menjadi empat fungsi yang tebagi kepada penjelasan yang menjelaskan tentangfungsi media dalam pembagunan, yakni sebagai berikut.

a. Fungsi informasi

Fungsi Informasi, yaitu media massa yang pertama dan utama. Khalayak pembaca beralangganan atau membeli surat kabar karena memerlukan informasi mengenai beberapa hal di bumi ini, mengenai peristiwa yang terjadi, gagasan atau pikiran orang lain, apa yang dilakukan oleh orang lain, apa yang dikatakan oleh orang lain, dan sebagainya.

b. Fungsi edukasi

Fungsi edukasi, yaitu media massa berfungsi sebagaisarana pendidikan. Surat kabar dan majalah memuat tulisan-tulisan yang mengandung pengetahuan sehingga khalayak bertambah pengetahuannya. Fungsi mendidik ini bias secara implisit dalam bentuk atikel dan tajuk rencana. Kadang-kadang cerita besambung atau berita bergambar juga mengandung aspek pendidikan.

c. Fungsi hiburan

Hal-hal yang bersifat hiburan sering dimuat oleh surat kabar dan majalah untuk mengimbangi berita-berita berat (hard news) dan artikel yang berbobot. Isi surat kabar dan majalah yang bersifat hiburan biasa berbentuk cerita pendek, cerita bersambung, cerita bergambar, teka-teki silang, pojok, karikatur, dan lain sebagainya. Meskipun pemuatan isi mengandung hiburan, itu hanya untuk melemaskan ketegangan pikiran setelah para pembaca dihidangkan berita dan artikel yang berat.

d. Fungsi pengaruh

Fungsi mempengaruhi, yang menyebabkan massa memegang peran penting dalam kehidupan masyarakat. Napoleon pada masa jayanya pernah berkata ia lebih takut empat surat kabar daripada seratus serdadu dengan senapan bersangkur terhunus. Sudah tentu surat kabar yang ditakuti ini ialah surat kabar yang independent, yang bebas menyatakan pendapat, bebas melakukan social control, bukan surat kabar yang 
149 Tomi Hendra, Media Massa dalam Komunikasi Pembangunan Jurnal At-Taghyir : Jurnal Dakwah dan Pengembangan Masyarakat Desa Volume 1 Nomor 2 Juni 2019, h. 136-152

membawakan "his masteris Voice". Fungsi mempengaruhi dari surat kabar, secara implisit terdapat pada tajuk rencana dan artikel. ${ }^{11}$

Selanjutnya, maka yang harus menjadi mayoritas adalah pada fungsi informasi dan edukasi, artinya media massa diharapkan dapat lebih banyak memberikan informasi dan pembangunan kepada masyarakat atau komunikatornya dibandingkan dengan fungsi hiburan dan fungsi pengaruhnya. Sehingga dengan demikian, diharapkan kehadiran media massa akan lebih banyak memberikan manfaat kepada masyarakat luas. Akan tetapi yang terjadi sekarang adalah bahwa media massa terutama media elektronik lebih mendominasi dalam hal hiburan atau entertainment. Sebenarnya inilah yang menjadi permasalahan dimana kehadiran media massa kurang banyak memberikan manfaat, bahkan cenderung merugikan masyarakat terutama pada perubahan karakter masyarakat akibat tayangan yang disajikan. Misalnya tayangan sinetron atau informasi tentang aksi kejahatan semisal penganiayaan, maka sebenarnya tayangan tersebut tidaklah menguntungkan masyarakat, bahkan sebenarnya merugikan masyarakat, karena masyarakat akan lebih banyak mendapat tayangan yang berbau hal negatif atau sesuatu yang dilebih lebihkan. Oleh sebab itu, perlu ada suatu tatanan yang proporsional dalam menjalankan fungsi media massa, dimana yang harus menjadi titik fokus adalah pada fungsi edukasi dan informasi. Maka dengan demikian diharapkan kehadiran media massa dapat memberikan manfaat yang lebih optimal lagi kepada masyarakat. ${ }^{12}$

Media juga berfungsi pembuat keputusan secara umum pada pikiran masyarakat, karena media berperan sebagai penunjang yang dipikirkan oleh masyarakat untuk memutuskan sesuatu yang diinginkan. Dengan fungsi ini, media menuntut alam bawah sadar pada kelompok-kelompok masyarakat yang sejak pagi hari, malam hari, atau kapan saja yang duduk di kedai, warung, pos ronda, majlis taklim, ruang kantor sambil memperbincangkan pimpinnya, ruang DPR, yang akan membuat keputusan perubahan situasi, yang bahan diskusinya telah ada pada pada berita yang ada di media. ${ }^{13}$

${ }^{11}$ Onong Uchajana Effendi, Komunikasi Teori Dan Praktek,(Bandung: Rosda Karya, 2011), hlm.149-150

${ }^{12}$ http://zulfanlitur.blogspot.com/2014/03/makalah-komunikasi-pembangunan.html (diakses, 13/4/2015, 11:23)

${ }^{13}$ Wakidul Kohar, al munir 2: Jurnal Ilmiah Dakwah Dan Komunikasi, (Jurusan Komunikasi Penyiaran Islam Fdik Ib Padang: 2014) 
150 Tomi Hendra, Media Massa dalam Komunikasi Pembangunan Jurnal At-Taghyir : Jurnal Dakwah dan Pengembangan Masyarakat Desa Volume 1 Nomor 2 Juni 2019, h. 136-152

\section{Media sebagai Penggerak Pembangunan}

Dalam proses penyebaran informasi lewat media massa, paling tidak ada beberapa hal yang diperlukan dalam menyusun untuk menyampaikan suatu informasi. Perihal tersebut tersebut adalah perhatian, kebtuhan pemuasan, visualisasi, dan tindakan. Hingga akhirnya ia akan terdorong untuk bertindak sesuai dengan media yang diterimanya. Dimana bangunan konstrusi citra oleh media massa terbentuk dalam dua model diantaranya modelgood news (citra yang baik) dan model badnews ( citra yang baik). ${ }^{14}$ Di bidang teknis dan teknologis tercatat banyak kemajuan yang mendukung pertumbuhan dan perkembangan komunikasi. Apabila pada decade 50-an, masalahnya masih berkisar pada pembagian gelombang pendek siaran radio, maka dewasa ini masalahnya telah berkembang menjadi masalah yang menyangkut system satelit dunia, dimana tidak ada lagi Negara di dunia ini merasa tidak berkepentingan. ${ }^{15}$

Pembangunan merupakan sebuah usaha yang dilakukan, dimana usaha-usaha mengembangkan masyarakat dilakukan agar mereka memperoleh peningkatan kehidupan dan kesejahteraan, baik dari sisi material maupun sisi spritual. Sejatinya pembangunan dapat dilakukan oleh siapa saja, oleh berbagai pihak apakah negara, lembaga ataupun individu. Sementara itu keberhasilan proses pembangunan memerlukan bantuan berbagai aspek. Salah satunya adalah memanfaatkan berbagai jenis media dalam proses pembangunan. Pemanfaatan media dalam pembangunan adalah satu hal yang mutlak. Tanpa media, pembangunan tidak mungkin dilakukan dengan maksimal. Dan pada akhirnya keberhasilan pembangunan tersebut menjadi sebuah keniscayaan. Banyak media dapat dimanfaatkan, seperti : media radio, televisi, surat kabar bahkan internet. Beberapa studi dalam kajian komunikasi pembangunan menunjukkan bahwa media dapat menunjang suksesnya pembangunan.

Seiring semakin pesatnya perkembangan teknologi komunikasi, maka pemanfaatan media komunikasi massa menjadi semakin besar. Media televisi, radio, surat kabar, bahkan internet menjadi sarana menyampaikan pesan-pesan pembangunan masyarakat. Media yang semakin canggih amat memungkinkan mengemas pesan pembangunan menjadi semakin kreatif dan menarik. Pada tahun 50-an, 60-an sampai

\footnotetext{
${ }^{14}$ Toni hartono, dkk, Komunikasi Dakwah, (Pekanbaru: Yayasan Pustaka Riau, 2011), hlm. 135

${ }^{15}$ Hamoko, komuniasi sambung rasa, (Jakarta: sinar harapan, 1986), hl, 120
} 
151 Tomi Hendra, Media Massa dalam Komunikasi Pembangunan Jurnal At-Taghyir : Jurnal Dakwah dan Pengembangan Masyarakat Desa Volume 1 Nomor 2 Juni 2019, h. 136-152

70-an, media massa amat dominan berperan dalam pembangunan di negara berkembang.Indonesia sendiri menjadi negara ke-4 di asia yang memiliki siaran televisi setelah Jepang, Filifina dan Thailand. ${ }^{16}$ Kondisi media massa, khususnya televisi di Indonesia saat ini, merupakan fenomena ang sangat menarik, hal ini disebabkan pesatnya perkembangan media dan masyarakat dalam memasuki era pembangunan. Perkembangan iklan televisi telah menepis perkiraan banyak kalangan bahwa sector iklan televisi di Indonesia terpengaruh oleh kondisi ekonomi hal ini dapat dibuktikan. ${ }^{17}$

Dalam proses ini ada beberapa pertimbangan yang perlu perkembangan media sebagai penggerak pembangunan, yaitu:

a. Perkembangan media sampai pada satuan kecil masyarakat membuat kita harus membuat sikap baru dan lebih kompleks terhadap terminologi-terminologi sosial tradisional yang diyakini oleh masyarakat.

b. Perkembangan media massa baru seperti televisi sempat mengubah persepsi sosial masyarakat karena pengaruhnya yang sedemikian dahsyat. Bahkan dapat dikatakan bahwa televisi mampu menjadi sentra kehidupan sosial meski tidak menutup kemungkinan bahwa media cetak juga tetap mempunyai kekuatan yang cukup signifikan dalam masyarakat.

c. Proses transisi sosial baru yang dialami oleh masyarakat menuntut kita untuk memperbaharui konsep sosial yang sudah ada.

d. Pemahaman tentang ini juga akan mempengaruhi keseluruhan sikap yang diambil dalam proses perkembangan budaya masyarakat itu sendiri.

\section{Kesimpulan}

Saat ini media massa sudah dijadikan sebagai alat atau senjata baik bagi individu atau kelompok untuk menyebarkan informasi dalam rangka mewujudkan berbagai macam kepentingan. Sebagaimana yang telah dijelaskan di atas bahwa media sangat penting dalam proses pembangunan, baik bagi media itu sendiri maupun bagi masyarakat luas. Apalagi dengan mengingat media massa yang telah diberikan hak kebebasan untuk mengeluarkan suara atau opini-opini public baik itu tentang kebijakan

\footnotetext{
${ }^{16}$ Muhammad Mufid, Komunikasi Dan Regulasi Penyiaran,(Jakarta: Kencana, 2007),hlm.48

17 Burhan Bungin, konstruksi sosial media massa: kekuatan pengaruh media massa, iklan televise, dan keputusan konsumen serta kritik terhadap peter l. \& thomas luckman,(Jakarta: Kencana, 2008), hlm. 201
} 
152 Tomi Hendra, Media Massa dalam Komunikasi Pembangunan Jurnal At-Taghyir : Jurnal Dakwah dan Pengembangan Masyarakat Desa Volume 1 Nomor 2 Juni 2019, h. 136-152

pemerintah atau isu-isu lainnya. Dari sisi perannya media massa tidak bisa dipisahkan dengan masyarakat karena saling terkait satu sama lainnya. Pada intinya dalam media massamendapatkan simpati dari masyarakat harus melakukan pendekatan terhadap masyarakat. Agar media yang diharapkan dapat teraktualisasi secara tepat, maka butuh wadah atau media yang memfasilitasi, yaitu media massa. Media massa disini dapat berbentuk media cetak seperti koran, majalah, rekalame, pamflet, sticker, ataupun media massa elektronik seperti televisi, radio, dan Internet sebagai media yang mengalami kemajuan di dunia dalam pembangunan Dengan media massa, pembangunan dalam mencapai tujuan akan mudah tersampaikan pada masyarakat.

\section{Daftar Kepustakaan}

Amin, Samsul, Rekonstruksi Pemikiran Dakwah Islam, (Jakarta: Amzah, 2008)

Aziz, Moh Ali, Ilmu Dakwah, (Jakarta: Kencana, 2009)

Burhan Bungin, Konstruksi Sosial Media Massa: Kekuatan Pengaruh Media Massa, Iklan Televisi, Dan Keputusan Konsumen Serta Kritik Terhadap Peter L. \& Thomas Lucknam, (Jakarta: Kencana, 2008)

, Sosiologi Kontruksi: Teori, Paradigm, dan Diskursus Teknologi

Komunikasi di Masyarakat, (Jakarta: Kencana Prenada Media Group, 2011)

Djuroto, Totok, Penerbitan Pers, (Bandung: Remaja Rosda Karya, 2002)

Effendi Onong Uchajana, Komunikasi Teori dan Praktek, (Bandung: Rosda Karya, 2011).

Harun, Rochajat dan Ardianto, Elvinaro Komunikasi Pembangunan Perubahan Sosial, (Jakarta: Rajawali Perss, 2012)

Harmoko, Komunikasi Sambung Rasa, (Jakarta: Sinar Harapan, 1989)

Hartono, Toni dkk, Komunikasi Dakwah, (Pekanbaru: Yayasan Pusaka Riau, 2011)

Kohar, Wakidul, Al Munir 2: Jurnal Ilmiah Dakwah Dan Komunikasi, (Jurusan Komunikasi Penyiaran Islam Fdik Ib Padang: 2014)

Marijan, Kacung System Politik Indonesia: Konsolidasi Demokrasi Pasca Orde Baru, (Jakarta: Kencana, 2010)

Mufid, Muhammad, Komunikasi dan Regulasi Penyiaran. (Jakarta: Kencana, 2007)

Rukminto Adi, Isbandi, Psikologi, Pekerjaan Sosial dan Ilmu Kesejahteraan Sosial, Dasar-Dasar Pemikiran, (Jakarta: Raja Grafindo Persada, 1994)

Syarif, Naqif, Menjadi Dakwah Yang Dicintai: Menyampaikan Dakwah Dengan Cara Yang Efektif, (Jakarta: Gramedia Pustaka Utama, 2011) 